\title{
Contrasting ecological implications of food limitation in sea urchins and herbivorous gastropods
}

\author{
N. L. Andrew \\ School of Biological Sciences and Institute of Marine Ecology, University of Sydney, NSW 2006, Australia
}

\begin{abstract}
Populations of sea urchins often fluctuate greatly in density. The density of sea urchins is usually inversely correlated with the abundance of macrolagae. It is argued that fluctuations in density are a predictable consequence of the unique morphology and physiology of sea urchins. An extraordinary ability to accomodate food limitation through variations in growth rate means that survivorship and food abundance are largely decoupled. These features of sea urchins differ from those of the herbivorous gastropods. The ecological implications of these differences are discussed. A different perspective is required for the interpretation of the population dynamics of sea urchins.
\end{abstract}

Sea urchins are relatively large, conspicuous members of marine communities. They are often aggregated (see Lawrence 1975, Warner 1979, Sloan 1980, Lawrence \& Sammarco 1982 for reviews) and populations may fluctuate in density with time (Lang \& Mann 1976, Foreman 1977. Andrew \& Choat 1982; see Lawrence 1975, Lawrence \& Sammarco 1982, Ebert 1983 for reviews). Because of these general features of their ecology sea urchins have been conspicuous in studies that seek to isolate and explain the processes that structure marine communities. These studies have shown that sea urchins can have a profound influence on the structure of benthic communities (Ogden et al. 1973, Estes \& Palmisano 1974, Duggins 1980, Andrew \& Choat 1982, Dean et al. 1984, Dayton 1985; see Lawrence 1975, Lawrence \& Sammarco 1982 for reviews).

In this note I argue that the great, though variable, impact sea urchins can have on communities is a predictable consequence of their unique morphology and physiology. It is suggested that the contribution of the morphology and physiology of sea urchins in determining the strength and consequences of interactions both within and between trophic levels has been largely unexplored. A greater appreciation of the consequences of morphology in sea urchins, and by exten- sion asteroids, will promote a different perspective for the interpretation of their population dynamics.

The uniqueness of the sea urchins may be illustrated by contrasting them with an ecologically similar, yet fundamentally different group of animals, the herbivorous gastropods. Echinoderms have a simple body plan, with relatively little development of muscle and small investment in soft tissue (see references in Jangoux \& Lawrence 1982). Gastropods have a more highly developed musculature, especially in the large muscles on which they are reliant for locomotion and adhesion to the substratum (see references in Fretter \& Graham 1962, Branch 1981).

High densities of sea urchins may persist for many years in situations of low food availability (Lang \& Mann 1976, Wharton \& Mann 1981, Andrew \& Choat 1982, Himmelman et al. 1983; see Lawrence 1975 for review). Much of this ability may be explained by reference to their morphology and physiology. Sea urchins show a great sensitivity to the availability of nutrients (Lawrence \& Lane 1982). Under conditions of limiting food they differentially allocate resources to various components of the body (Ebert 1980, Black et al. 1982, 1984). If the shortage of food is sufficiently great they resorb skeletal material and shrink (Ebert 1967, 1968, Dix 1972, Moss \& Lawrence 1972, Levitan 1988). Moreover, they can quickly capitalise on situations in which food is readily available, either by rapid production of gametes or by rapid somatic growth (Vadas 1977, Larson et al. 1980, Keats et al. 1982, Andrew 1986; see Lawrence \& Lane 1982 for review). These facts give the impression of a general architecture and level of morphological and physiological complexity that is well equipped to cope with limited availability of food (see also Johnson \& Mann 1982, Dean et al. 1984). The great plasticity of growth in echinoids should mean that they are less vulnerable to 
density-dependent mortality than gastropods. In short, it should be much harder to starve an echinoid to death than a herbivorous gastropod.

Many experimental studies have produced evidence consistent with density-dependent mortality in species of gastropod molluscs: Patella cochlear (Branch 1975), Acmaea scutulatum (Stimson \& Black 1975), Acmaea digitalis (Choat 1977). Nerita atramentosa (Underwood 1976, 1978), Patelloida latistrigata (Creese 1980, 1982), P. alticostata (Fletcher \& Creese 1985), Cellana tramoserica (Underwood 1978, Creese \& Underwood 1982, Underwood et al. 1983, Fletcher \& Creese 1985), Bembicium auratum (Branch \& Branch 1980), Notoacmea petterdi (Creese 1980), Littorina unifasciata (Branch \& Branch 1981), Siphonaria denticulata and $S$. virgulata (Creese \& Underwood 1982), Fissurella virescens (Ortega 1985), Tegula auratum (Schmitt 1985), Cellana stellifera (Choat \& Andrew 1986; see also Underwood 1979. Branch 1981, 1984 for reviews).

Although experimental studies of the effects of intraspecific competition for food in echinoids are few, the available information supports the contention that density-dependent mortality is less prevalent in sea urchins. Only Keller (1984) presented experimental evidence for density-dependent mortality, in the tropical echinoids Tripneustes ventricosus and Lytechinus variegatus. In the latter species little mortality occurred until densities reached 16 times their natural levels. It is difficult, therefore, to ascribe any importance to intraspecific competition for food as a process regulating the abundance of this species. T. ventricosus, in contrast, was susceptible to density-dependent process within the range of natural densities.

Evidence consistent with a lack of mortality with increasing density has been found in the echinoids Diadema antillarum (Sammarco 1980, Levitan 1988), Evechinus chloroticus (Andrew 1986, Choat \& Andrew 1986), Strongylocentrotus droebachiensis (Larson et al. 1980, Thompson 1982), and S. franciscanus (Vadas 1977). Ebert (1977) confined S. franciscanus and $S$. purpuratus in experimental enclosures and found that, within the treatments in which individuals were at higher densities, density decreased over time. However, diffusion of sea urchins among enclosures was sufficient for Ebert to conclude '.. that densitydependent mortality was not a significant feature of the experiment' (Ebert 1977, p. 19). Similarly a number of studies did not find density-dependent mortality in gastropods (e.g. Frank 1965, Black 1977, Choat 1977. Branch \& Branch 1981, Underwood 1984, Schmitt 1985, Choat \& Andrew 1986)

An essential caveat in the acceptance of these contrasts of the prevalence of density-dependent mortality in the sea urchins and herbivorous gastropods lies in the nature of the tests that provide evidence 'for' or 'against' density-dependent mortality. Demonstrations of density-dependence caused by intra-specific competition require not only that competition have a measurable effect on numbers of individuals, but also that the researcher correctly recognises the resource(s) for which competition is postulated (Peterson \& Andre 1980, Underwood 1984). Further, comparisons of the frequency of occurrence of density-dependent mortality require that those resources be placed under sufficiently severe but realistic, and comparable, degrees of short-supply. Failure to do so will mean that density dependence may not be detected when it is a real determinant of numbers in nature. There is, therefore an asymmetry in the worth, and meaning, of experimental tests for density-dependence that produce 'significant' results and those that do not. A lack of statistical significance does not mean that density dependence does not contribute to the abundance of sea urchins. These qualities of a falsificationist methodology mean that simple ratios of the number of studies 'for'/number of studies 'against' are inappropriate indicators of the relative prevalence of densitydependence in the 2 groups. These cautions notwithstanding, the overwhelming imbalance in the relative frequency of demonstrations of densitydependent mortality between the sea urchins and herbivorous gastropods suggests a broad generality. Clearly, more experimental tests of hypotheses concerned with the occurrence of density-dependent mortality in the 2 groups are required before any inductive argument based on the frequency of occurrence can gain general acceptance.

Several reasons for the relative invulnerability of sea urchins to density-dependent mortality may be suggested. In reviewing the nutrition of postmetamorphic echinoderms, Lawrence \& Lane (1982) stated that one of several characteristics of echinoderms is a low requirement of nutrients for respiration. Lawrence \& Lane believed that one of the reasons for this low energy requirement is the lack of muscular development in the echinoderms. Webster (1975) contrasted the respiration rates of species from several invertebrate phyla and concluded that the respiration rates of echinoderms were consistently among the lowest. Webster cited 3 possible causes for a low respiration rate in echinoderms: (1) a relatively inefficient oxygen transport system; (2) a relatively high proportion of metabolically inert skeletal material and a large volume of perivisceral fluid which has a low level of metabolic activity; and (3) a low level of activity.

If we accept that there is a major difference between the 2 groups in their energy requirements and, more importantly, in the consequences of a shortage of food, then the obvious ecological implication is that a tighter. and therefore more predictable, relationship should 
exist between the density of gastropods and the abundance of food than for sea urchins. Sea urchins are more able to accommodate food-stressed situations through adjustments in growth, and therefore the total biomass of echinoids in a population (Ebert 1968), rather than reductions in population size.

The decoupling of food availability and survivorship has important consequences for studies that seek to understand the regulation of numbers of echinoids, for it makes great variability in the density of local populations more explicable, but less predictable. If external forces operate to a greater degree to control their numbers, then variation is to be expected. By their very nature, processes that act on the individual from without will be more variable and less predictible than intrinsic processes

If freed from compensatory mortality, variability in recruitment will become more important in determining population densities and may provide substantial explanation for large fluctuations in density. Variable recruitment has been documented in both echinoids and gastropods (Ebert 1968, Foreman 1977; see Underwood 1979, Ebert 1983 for reviews); however, the consequences will differ considerably between groups. The morphology and physiology of the echinoids would, all else being equal, allow a greater survivorship than would occur in gastropods.

Attempts to explain large fluctuations in the density of sea urchins have often invoked changes in the magnitude of a regulatory process, such as predation (e.g. Estes \& Palmisano 1974, Breen \& Mann 1976, Duggins 1980, Tegner 1980; see Lawrence 1975, Lawrence \& Sammarco 1982 for reviews). Variations in the abundance of echinoids, and consequent effects on community structure, may also be a consequence of the combined effects of variable recruitment and an ability to survive stress. The degree to which predation is densitydependent is unclear. The crevice-dwelling behaviour of diadematid species may expose them to greater predation pressure where suitable refuges are in short supply (Nelson \& Vance 1979, Carpenter 1984). Strongylocentrotids, in contrast, may find refuge from predation in dense aggregations (Duggins 1983). In recent years several case-histories have documented decimation of populations of echinoids by disease over large geographic regions, e.g. California (Pearse et al. 1977), Nova Scotia (Miller \& Colodey 1983), and the Caribbean sea (Lessios et al. 1983). The extent to which this pathogen operates in a density-dependent manner is unknown.

Although I have concentrated on the contrasting morphologies and physiologies of sea urchins and gastropods, other echinoderms share some of the same morphological attributes that would buffer them from the compensatory effects of density-dependent mortality (see Emson \& Wilkies 1980 for review). Asteroids are commonly found at high densities and can have a great impact on their environment (Paine 1969, Sloan 1980). For example, the large asteroid Acanthaster planci is often found in dense aggregations and can increase in density to populations of sufficient magnitude to earn the appellation 'outbreaks' (see Potts 1981, Moran 1986 for reviews). The devastating effect this species can, and does, have on coral communities throughout the tropical Indo-Pacific region has resulted in a continuing controversy concerning the processes that regulate the abundance of $A$. planci (see Potts 1981, Moran 1986 for reviews). If the ideas presented have any generality then the numbers of $A$. planci will not be regulated by food availability. Hypotheses concentrating on recruitment variability and foraging behaviour may be more profitable than those that seek an explanation via the actions of a man-induced change in predation intensity.

I have argued that the consequences of intra-specific competition for food to the population ecology of sea urchins, and by extension asteroids, is much less servere than for the herbivorous gastropods. In taking this line of reasoning it was implicitly assumed that the intensity of competition is correlated with its importance in the determination of population size. Welden $\&$ Slauson (1986) have made a convincing case that this need not be so. The importance of competition to the population ecology of a species cannot be considered without reference to other processes, such as predation or disease. Few of the studies considered provide information that allows a direct assessment of the relative importance of competition for food. I reason that morphology and physiology acts to decrease the importance of competition by increasing the range of states between 'optimal' and lethal. Competition of the same intensity will therefore be of proportionally less importance in the echinoids.

The sensibilities gained from the study of organisms such as gastropods seem ill suited to the study of the population dynamics of echinoderms such as echinoids and asteroids. I predict that competition for food will be found to play a less important role in determining the population densities of these organisms than it does in other groups, such as the gastropod molluscs. Extrinsic processes such as predation and the forces that determine the number of recruits entering a benthic population will have a greater role to play than the more deterministic and stabilising effects of density-dependent mortality

Acknowledgements. I thank D. T. Anderson, J. H. Choat, M. S. Foster, G. P. Jones, J. M. Lawrence, D. R. Schiel, L. J Stocker, and A. J. Underwood for discussion during the protracted preparation of this discussion and for comments on the manuscript. I also thank D. R. Levitan, who has independently developed many of the predictions introduced here, for discussion and comment. 


\section{LITERATURE CITED}

Andrew, N. L. (1986). The interaction between diet and density in influencing reproductive output in the echinoid Evechinus chloroticus (Val.). J. exp. mar. Biol. Edol. 97 : $63-79$

Andrew, N. L., Choat, J. H. (1982). The influence of predation and conspecific adults on the survivorship of juvenile Evechinus chloroticus (Echinoidea: Echinometridae) Oecologia (Berl.) 54: 80-87

Black, R. (1977). Population regulation in the intertidal limpet Patelloida alticostata (Angas, 1865). Oecologia (Berl.) 30: 9-22

Black, R., Johnson, M. S., Trendall, J. T. (1982). Relative size of Aristotle's latern in Echinometra mathaei occurring at different densities. Mar. Biol. 71: 101-106

Black, R., Codd, C., Hebbert, D., Vink, S., Burt, J. (1984). The functional significance of the relative size of Aristotle's lantern in the sea urchin Echinometra mathaei (deBlainville). J. exp. mar. Biol. Ecol. 77: 81-97

Branch, G. M. (1975). Intraspecific competition in Patel cochlear Born. J. Anim. Ecol. 44: 263-282

Branch, G. M. (1981). The biology of limpets: physical factors, energy flow and ecological interactions. Oceanogr mar Biol. A. Rev. 19: 235-379

Branch, G. M. (1984). Competition between marine organisms: biological and evolutionary implications. Oceanogr mar. Biol. A. Rev. 22: 950-958

Branch, G. M., Branch, M. L. (1980). Competition in Bembicium auratum (Gastropoda) and its effects on microalgal standing stock in mangrove muds. Oecologia (Berl.) 46: 106-114

Branch, G. M., Branch, M. L. (1981). Experimental analysis of intraspecific competition in an intertidal gastropod, Littorina unifasciata. Aust. J. mar. Freshwat. Res. 32: 573-589

Breen, P. A., Mann, K. H. (1976). Changing lobster abundance and the destruction of kelp beds by sea urchins. Mar. Biol. $34: 137-142$

Carpenter, R. C. (1984). Predator and population density control of homing behaviour in the Caribbean echinoid Diadema antillarum. Mar Biol 82: 101-108

Choat, J. H. (1977). The influence of sessile organisms on the population biology of three species of acmaeid limpets. J. exp. mar. Biol. Ecol. 26: 1-26

Choat, J. H., Andrew, N. L. (1986). Interactions amongst species in a guild of subtidal benthic herbivores. Oecologia (Berl.) 68: 387-394

Creese, R. G. (1980). An analysis of distribution and abundance of populations of the high-shore limpet Notoacmea petterdi (Tenison-Woods). Oecologia (Berl.) 45: 252-260

Creese, R. G. (1982). Distribution and abundance of populations of the high shore limpet Patelloida latistrigata, and its interaction with barnacles. Oecologia (Berl.) 52: 85-96

Creese, R. G., Underwood, A. J. (1982). Analysis of inter- and intra-specific competition amongst intertidal limpets with different methods of feeding. Oecologia (Berl.) 53: 337-346

Dayton, P. K. (1985). Ecology of kelp forests. A. Rev. Ecol. Syst. 16: $215-245$

Dean, T A., Schroeter, S. C., Dixon, J. D. (1984). Effects of grazing by two species of sea urchins (Strongylocentrotus franciscanus and Lytechinus anamesus) on recruitment and survival of two species of kelp (Macrocystis pyrifera and Pterogophora californica). Mar Biol. 78: 301-313

Dix, T G. (1972). Biology of Evechinus chloroticus (Echinoidea: Echinometridae) from different localities. 4 Age, growth and size, N.Z. J. mar. Freshwat. Sci. 6: 48-68
Duggins, D. O. (1980). Kelp beds and sea otters: an experimental approach. Ecology 61. 447-453

Duggins, D. O. (1983). Interspecific facilitation in a quild of benthic marine herbivores. Oecologia (Berl.) 48: 157-163

Ebert, T A. (1967). Negative growth in the purple sea urchin Strongylocentrotus purpuratus (Stimpson). Science 157 $557-558$

Ebert, T A. (1968). Growth rates of the sea urchin Strongylocentrotus purpuratus related to food availability and spine abrasion. Ecology 49: 1075-1091

Ebert, T A. (1977). An experimental analysis of sea urchin dynamics and community interactions on a rock jetty. $J$. exp. mar. Biol. Ecol. 27: 1-22

Ebert, T A. (1980). Relative growth of sea urchin jaws: an example of plastic resource allocation. Bull. mar. Sci, 30: $467-474$

Ebert, T. A. (1983). Recruitment in echinoderms. Echinoderm Studies 1: 169-203

Emson, R. H., Wilkies, J. C. (1980). Fission and autotomy in echinoderms. Oceanogr. mar. Biol. A. Rev. 18: 155-250

Estes, J. A., Palmisano, J. F. (1974). Sea otters: their role in structuring nearshore communities. Science 185: $1058-1060$

Fletcher, W. J., Creese, R. G. (1985). Competitive interactions between co-occurring herbivorous gastropods. Mar. Biol 86: $183-191$

Foreman, R. E. (1977). Benthic community modification and recovery following intensive grazing by Strongylocentrotus droebachiensis. Helgoländer wiss. Meeresunters 30 $468-484$

Frank, P. W (1965). Life histories and community stability Ecology 49: 355-357

Fretter, V., Graham, A. (1962). British prosobranch molluscs The Ray Society, London

Himmelman, J. H., Lavergne, Y., Axelson, F., Cardinal, A Bourget, E. (1983). Sea urchins in the Saint Lawrence estuary; their abundance, size-structure, and suitability for commercial exploitation. Can. J. Fish. Aquat. Sci. 40 $474-486$

Jangoux, M., Lawrence, J. M. (1982). Echinoderm nutrition. A A. Balkema Press, Rotterdam

Johnson, C. R., Mann, K. H. (1982). Adaptations of Strongylocentrotus droebachiensis for survival on barren grounds in Nova Scotia. In: Lawrence, J. M. (ed.) International Echinoderms Conference, Tampa Bay. A. A. Balkema, Rotterdam, p. 277-283

Keats, D. W., South, G. R., Steele, D. H. (1982). The occurrence of Agarum cribrosum (Mert.) Bory (Phaeophyta, Laminariales) in relation to some of its competitors and predators in Newfoundland. Phycologia 21: 189-191

Keller, B. D. (1984). Coexistence oif sea urchins in seagrass meadows: an experimental analysis of competition and predation. Ecology 64: 1581-1598

Lang, C., Mann, K. H. (1976). Changes in sea urchin populations after the destruction of kelp beds. Mar. Biol. 36: 321-326

Larson, B. R., Vadas, R. L., Keser, M. (1980). Feeding and nutritional ecology of the sea urchin Strongylocentrotus droebachiensis in Maine, USA. Mar. Biol. 59: 49-62

Lawrence, J. M. (1975). On the relationships between marine plants and sea urchins. Oceanogr mar Biol. A. Rev. 13: $213-286$

Lawrence, J. M., Lane, J. M. (1982). The utilization of nutrents by postmetamorphic echinoderms. In: Jangoux, M., Lawrence, J. M. (eds.) Echinoderm nutrition. A. A. Balkema. Rotterdam, p. 331-371

Lawrence, J. M., Sammarco, P. W. (1982). Effects of feeding on 
the environment: echinoidea. In: Jangoux, M., Lawrence, J. M. (eds.) Echinoderm nutrition. A. A. Balkema, Rotterdam, p. 499-519

Lessios, H. A., Glynn, P. W., Robertson, D. R. (1983). Mass mortality of coral reef organisms. Science 222: 715

Levitan, P. R. (1988). Density-dependent size regulation and negative growth in the sea urchin Diadema antillarum Philippi. Oecologia (Berl.) 76: 627-629

Miller, R. J., Colodey, A. G. (1983). Widespread mass mortalities of the green sea urchin in Nova Scotia, Canada. Mar. Biol. 73: 263-267

Moran, P. J. (1986). The Acanthaster phenomenon. Oceanogr mar. Biol. A. Rev. 24: 379-480

Moss, J. E., Lawrence, J. M. (1972). Changes in carbohydrate, lipid and protein levels with age and season in the sand doller Mellita quinquiesperforata. J. exp. mar. Biol. Ecol. 8: 225-239

Nelson, B. V., Vance, R. R. (1979). Diel foraging patterns of the sea urchin Centrostephanus coronatus as a predator avoidance strategy. Mar. Biol. 51: 251-258

Ortega, S. (1985). Competitive interactions amongst tropical intertidal limpets. J. exp. mar. Biol. Ecol. 90: 11-25

Ogden, J. C., Brown, R. C., Salensky, N. (1973). Grazing by the echinoid Diadema antillarum Phillipi: formation of halos around West Indian patch reefs. Science 182: $715-717$

Paine, R. T (1969). A note on trophic complexity and community stability. Am. Nat. 103: 91-93

Pearse, J. S., Costa, D. P., Yellin, M. B., Agegian, C. R. (1977). Localized mass mortality of red sea urchin, Strongylocentrotus franciscanus, near Santa Cruz, California. Fish. Bull. U. S. 75: 645-648

Peterson, C. H., Andre, S. (1980). An experimental analysis of interspecific competition among marine filter feeders in a soft-sediment evironment. Ecology 61: 129-139

potts, D. C. (1981). Crown-of-thorns starfish - man-induced pest or natural phenomenon? In: Kitching, R. L., Jones, R. E. (eds.). The ecology of pests - some Australian case histories. CSIRO, Melbourne, p. 55-86

Sammarco, P. W. (1980). Diadema and its relationship to coral spat mortality: grazing, competition, and biological disturbance. J. exp. mar. Biol. Ecol. 45: 245-272

Schmitt, R. J. (1985). Competitive interactions of two mobile prey species in a patchy environment. Ecology 66: 950-958

Sloan, N. A. (1980). Aspects of the feeding biology of asteroids. Oceanogr. mar. Biol. A. Rev. 18: 57-124
Stimson, J., Black, R. (1975). Field experiments on population regulation in intertidal limpets of the genus Acmaea. Oecologia (Berl.) 18: 111-120

Tegner, M. J. (1980). Multispecies considerations of resource management in southern California kelp forests. In: Proceedings of the workshop on the relationship between sea urchin grazing and commercial plant/animal harvesting. Can. Tech. Rep. Fish. Aquat. Sci.: 125-143

Thompson, R. J. (1982). The relationship between food ration and reproductive effort in the green sea urchin, Strongylocentrotus droebachiensis. Oecologia (Berl.) 56: $50-57$

Underwood, A. J. (1976). Food competition between ageclasses in the intertidal neritacean Nerita atramentosa Reeve (Gastropoda: Prosobranchia). J. exp. mar. Biol. Ecol. 23: $145-154$

Underwood, A. J. (1978). An experimental evaluation of competition between three species of intertidal prosobranch gastropods. Oecologia (Berl.) 33: 185-202

Underwood, A. J. (1979). The ecology of intertidal gastropods. Adv. mar. Biol, 16: 111-210

Underwood, A. J. (1984). Microalgal food and the growth of the intertidal gastropods Nerita atramentosa Reeve and Bembicium nanum (Lamarck) at four depths on a shore. J. exp. mar. Biol. Ecol. 79: 277-291

Underwood, A. J., Denley, E. J., Moran, M. J. (1983). Experimental analyses of the structure and dynamics of midshore rocky intertidal communities in N. S. W Oecologia (Berl.) 56: 693-700

Vadas, R. L. (1977). Preferential feeding: an optimization strategy in sea urchins. Ecol. Monogr. 47. 337-371

Warner, G. H. (1979). Aggregation in echinoderms. In: Larwood, G., Rosen, B. R. (eds.) Biology and systematics of colonial organisms. Academic Press, London, p. 375-396

Webster, S. K. (1975). Oxygen consumption in echinoderms from several geographical locations, with particular reference to the echinoidea. Biol. Bull. mar biol. Lab., Woods Hole 148: 157-164

Welden, C. W., Slauson, W. L. (1986). The intensity of competition versus its importance: an overlooked distinction and some implications. Q. Rev. Biol. 61: 23-44

Wharton, W. G., Mann, K. H. (1981). Relationship between destructive grazing by the sea urchin, Strongylocentrotus droebachiensis, and the abundance of American lobster, Homarus americanus, on the Atlantic coast of Nova Scotia. Can. J. Fish. Aquat. Sci. 38: 1339-1349 